\title{
Tratamento cirúrgico das hérnias discais foraminais pela microdiscectomia artroscópica
}

\author{
Surgical treatment of foraminal disc herniations by arthroscopic microdiscectomy
}

Pedro Vilela Machado Filho ${ }^{1}$, Alceu Gomes Chueire ${ }^{2}$

\section{RESUMO}

A hérnia discal lombar foraminal é extremamente incapacitante em relação à sintomatologia clínica. Nos últimos quarenta anos muitas alternativas foram propostas no tratamento dessa patologia. Vinte pacientes com essa síndrome radicular foram operados, via pósterolateral, pela técnica da microdiscectomia artroscópica. O acompanhamento foi realizado com questionários de auto-avaliação pré-operatória e pós-operatória sendo obedecidos rigorosamente os critérios de inclusão e exclusão para a indicação cirúrgica. A idade média dos pacientes foi de 43 anos, com variação de 23 a 58 anos. Houve predomínio do sexo feminino (13 pacientes e freqüência percentual de $65 \%$ ) em relação ao masculino (7 pacientes e freqüência percentual de $35 \%$ ). Todos os pacientes foram operados de hérnia discal lombar foraminal no nível entre as $4^{\mathrm{a}}$ e $5^{\mathrm{a}}$ vértebras lombares. Os resultados clínicos apresentaram um percentual de $75 \%$ de sucesso. Não ocorreram nesse estudo complicações, tais como: lesão nervosa motora, vascular ou discite bacteriana.

Descritores: Foraminal, Microdiscetomia, Artroscopia.

\section{INTRODUÇÃO}

As hérnias discais lombares laterais, foraminal ou extraforaminal, foram descritas por Dandy $(1941)^{(2)}$, Lindblom $(1944)^{(11)}$, Harris e Macnab (1954) $)^{(4)}$ e raramente eram reconhecidas clinicamente.

Abdullah et $a^{(1)}$, descreveu a clínica da hérnia discal lateral, propondo a tomografia axial computadorizada e a discografia como método diagnóstico e estabeleceu o tratamento com facetectomia medial que originava o quadro de instabilidade segmentar lombar. A hérnia discal foraminal é uma síndrome radicular aguda, com dor mais intensa na perna do que na coluna lombar, originada por uma ruptura discal na porção extracanalicular do canal medular (dentro das margens dos pedículos) e que comprime a raiz emergente longitudinal.

\section{SUMMARY}

Foraminal lumbar disc herniations are extremely handicapping in relation to clinical symptoms and over the last forty years many alternatives have been put forward for treatment. Twenty patients with this radicular syndrome were operated by posterolateral access using arthroscopic microdiscectomy. Success was evaluated using pre-operative and post-operative self-evaluation questionnaires. Inclusion and exclusion criteria for surgery were rigorously followed. The mean age of the patients was 43 years old, varying between 23 and 58 years old. The group consisted of 13 women (65\%) and 7 men (35\%). All patients underwent operations for foraminal lumbar disc herniations between the 4th and 5 th lumbar vertebrae. The success rate was $75 \%$ of the cases. No motor nerve or vascular lesions or bacterial discitis were evidenced.

Key words: Foraminal; Microdiscectomy; Arthroscopic.

\section{INTRODUCTION}

Foraminal and extraforaminal lateral lumbar disc herniations have been described by Dandy (1941)(2), Lindb/om (1944)(11), Harris \& MacNab (1954)(4) and were rarely seen in practice.

Abdullah et al ${ }^{(1)}$ described the clinical characteristics of lateral disc herniations and proposed computerized axial tomography and discography as diagnostic methods. He also established the treatment using medial facetectomy, which gave origin to lumbar segmental instability. Foraminal disc herniation is an acute radicular syndrome, with more intense pain in the leg than in the lower back, originating from a disc rupture in the extracanalicular portion of the medullary canal (within borders of the pedicles) and which compresses the longitudinal emerging root. That is, a foraminal disc between $L 4$ and $L 5$ causes tension on the $L 4$ root. The extraforaminal herniation is located laterally to the pedicle.
Trabalho realizado na Santa Casa de Misericórdia de São José do Rio Preto

1 - Chefe do Serviço de Ortopedia e Traumatologia da Santa Casa de Misericórdia de São José do Rio Preto, membro titular da SBOTSociedade Brasileira de Ortopedia e Traumatologia.

2 - Doutor em Ortopedia e Chefe do Departamento de Ortopedia e Traumatologia da Faculdade de Medicina de São José do Rio PretoFAMERP.

Endereço para correspondência: Rua Siqueira Campos, 1820 - Boa Vista - 15025055 - São José do Rio Preto-SP - fone: (17) 212-1500. e-mail: pedrohlv@terra.com.br

Trabalho recebido em 03/07/03. Aprovado em 06/04/04.
Work perfomed at the Santa Casa de Misericórdia de São José do Rio Preto

1 - Head of the Orthopaedics and Traumatology Service - Santa Casa de Misericórdia-São José do Rio Preto, member of SBOT - Brazilian Orthopaedics Society and SBPCV- Brazilian Spine Society.

2 - PhD inOrthopaedics. Head of Orthopaedics Department - Faculdade de Medicina de São José do Rio Preto - FAMERP

Adress: Rua Siqueira Campos, 1820 - Boa Vista - 15025-055 São José do Rio Preto-SP - phone: + 55 ( 17 ) 212-1500. e-mail: pedrohlv@terra.com.br 
Por exemplo: um disco foraminal no nível L4-L5 pressiona a raiz L4. A hérnia extraforaminal localiza-se lateral ao pedículo.

McCulloch e Young ${ }^{(13)}$ relataram que essas herniações acometem igualmente ambos os sexos. O nível mais freqüente é entre a $4^{a}$ e a $5^{a}$ vértebras lombares devido ser o segmento com mais mobilidade. A incidência deste tipo de hérnia é de 5 a 10\%. A faixa etária mais freqüente é acima dos 50 anos, com espaço discal normal nas radiografias e um início súbito de sintomatologia, sugerindo-se a origem traumática. A maioria das hérnias discais laterais irrita e comprime, parcial ou totalmente, o gânglio da raiz dorsal provocando uma sintomatologia dolorosa intensa.

Hijikata(5) $^{(5)}$, evidenciou 75\% de evolução satisfatória em seus pacientes submetidos à ressecção nuclear na abordagem endoscópica póstero-lateral.

$\mathrm{Na}$ década de $80^{(6)}$ os instrumentos foram modificados, aumentando-se o diâmetro da cânula para passagem de pinças especiais, facilitando a ressecção do disco lombar.

Subseqüentemente, Grenier, et $\mathrm{al}^{(3)}$ descreveram o valor da tomografia axial computadorizada e da ressonância magnética nuclear na identificação da herniação discal foraminal e extraforaminal.

Kambin et $\mathrm{a}^{(9)}$ desenvolveu os conhecimentos da anatomia artroscópica póstero-lateral descrevendo as delimitações do espaço de trabalho no anel fibroso. A disponibilidade de fibras ópticas de pequeno calibre permitiu a lateralização da entrada da agulha na pele e o posicionamento da extremidade aberta da cânula perineural. Kambin demonstrou que o princípio da microdiscectomia artroscópica baseava-se na ressecção de fragmentos discais herniados sob iluminação e intensificação da imagem. Essa técnica consiste em descomprimir o espaço dos discos intervertebrais, reduzindo o volume herniado do núcleo pulposo. A protrusão discal não migrada, com quadro clínico de uma irritação de raiz nervosa, constituiu a principal indicação do método.

O objetivo geral da dissertação é avaliar a técnica cirúrgica no tratamento das hérnias discais lombares foraminais com a microdiscectomia artroscópica em nosso meio, destacando-se suas vantagens e suas desvantagens.

\section{CASUÍSTICA E MÉTODO}

Vinte pacientes portadores de hérnias discais foraminais foram operados pela técnica da microdiscectomia artroscópíca. Todos foram tratados conservadoramente no prazo mínimo de 2 meses e máximo de 8 meses (média de 4 meses e 25 dias) e após a não obtenção de melhora indicou-se o tratamento cirúrgico . A idade média foi de 43 anos, com variação de 23 a 58 anos. Houve predomínio do sexo feminino (13 pacientes do sexo feminino com freqüência percentual de $65 \%$ e 7 pacientes do sexo masculino com freqüência percentual de $35 \%$ ). O nível abordado foi entre a $4^{\mathrm{a}}$ e $5^{\mathrm{a}}$ vértebras lombares no espaço foraminal. Houve predomínio do lado direito (11 pacientes $-55 \%$ ) em relação ao esquerdo ( 9 pacientes $-45 \%$ )

As ferramentas estatísticas utilizadas foram: tabelas de freqüências, análise exploratória de dados e gráficos de perfis individuais e médios. O "software" utilizado foi o STATDISK V.5.0.

As indicações para a cirurgia dependeram dos seguintes critérios de inclusão: 1) radiculopatia rebelde com mais de 8 semanas de duração ao nível da $3^{\mathrm{a}}$ e $4^{\mathrm{a}}$ ou $4^{\mathrm{a}}$ e $5^{\mathrm{a}}$ vértebras, que não obteve resultado com o tratamento conservador durante 8 semanas; 2) dor na perna mais intensa que nas costas; 3)piora do estado neurológico refletida pelos déficits sensitivos, anormalidades dos reflexos e paresia; 4) sinais de tensão da raiz nervosa (sinal de Lasègue positivo, sinal de Lasègue contra-lateral positivo, reprodução da dor radicular sob carga em flexão e rotação da coluna lombar); 5) estudos de imagens correlacionados com a clínica.
McCulloch and Young ${ }^{(13)}$ related this herniation is observed at the same rate both in men and women and is most frequently seen between the 4th and 5th lumbar vertebrae, as this is the segment with the greatest mobility. The incidence of this type of herniation is of between $5 \%$ and $10 \%$. It most commonly affects over 50-year-old patients with normal disc spacing as seen on radiographs and the sudden start of the symptoms suggests a traumatic origin. The majority of lateral disc herniations irritates and compresses, partially or totally, the ganglia of the dorsal root provoking intensely painful symptoms.

Hijikata ${ }^{(5)}$ evidenced a satisfactory evolution in $75 \%$ of his patients submitted to nuclear resection by the posterolateral endoscopic approach.

In the $1980 s^{(6)}$ the instruments were modified, increasing the diameter of the cannula for the passage of the special forceps, thus facilitating the resection of the lumbar disc.

Subsequently, Grenier, et al/(3) described the importance of computerized axial tomography and nuclear magnetic resonance in the identification of foraminal and extraforminal herniations.

Kambin et al(9) improved the understanding of the posterolateral arthroscopic anatomy describing the working space zone of the fibrous annulus. The availability of small-caliber optic fibers permitted the entrance of the needle in the skin to the side and the perineural placing of the open end of the cannula. These authors demonstrated that the principle of arthroscopic microdiscectomy is based on resection of herniated disc fragments using illumination and intensification of the image. This technique consists of opening the intervertebral disc space, reducing the herniated volume of the nucleus pulposus. The non-migrated disc protrusion, with a clinical symptom of irritation of the nerve root, is the principal indication of this method.

The general aim of this work is to evaluate the surgical technique in the treatment of foraminal lumbar disc herniations by arthroscopic microdiscectomy, highlighting its advantages and disadvantages.

\section{CASUISTIC AND METHOD}

Twenty patients suffering from foraminal lumbar disc herniations underwent surgery by arthroscopic microdiscectomy. All were previously treated conservatively over a period of between two and 8 months (average of 4 months 25 days). After this period, surgical treatment was indicated. The mean age of the patients was 43 years with a variation of between 23 and 58 years. The group consisted of 13 women (65\%) and 7 men (35\%). All the patients underwent operations for foraminal lumbar disc herniations between the 4th and 5th lumbar vertebrae. There was a predominance of the right side (11 patients - 55\%) compared to the left (9 patients - 45\%).

The statistical tools utilized were: Frequency tables, exploratory data analysis, graphs and individual and mean profiles. The software STATDISK V.5.0 was employed.

Indication for surgery depended on the following inclusion criteria: 1) severe radiculopathy between the 3rd and 4th or 4th and 5th vertebrae, which did not respond to conservative treatment of at least 8 weeks; 2) more intense pain in the leg than in the lower back; 3) worsening of the reflected neurological sensitivity deficits, reflex abnormalities and paresis; 4) signs of tension of the nerve root (positive Lasegue's sign, positive contralateral Lasegue's sign, reproduction of the radicular pain under flexion load and rotation of the lumbar column); 5) study of images correlating to the clinical symptoms. The exclusion criteria were. 
Os critérios de exclusão foram: 1) pacientes que não preencheram os requisitos do questionário pré-operatório; 2) síndrome da cauda eqüina; 3) hérnia discal extrusa e migrada intra-canal raquiano (extra-ligamentar, migrada); 4) tumores; 5) problemas psicossociais.

Todos os pacientes examinados responderam ao "questionário de auto avaliação pré-cirúrgica", sendo quantificado o grau de intensidade da dor, a freqüência da paresia e parestesia na perna afetada e o grau de capacidade para o trabalho. No acompanhamento ambulatorial foram respondidos os "questionários de auto avaliação póscirúrgica", nos $3^{\circ}$ e $6^{\circ}$ meses. O diagnóstico foi confirmado pelas imagens da tomografia axial computadorizada e/ ou ressonância magnética nuclear.

Os intrumentos usados na microdiscectomia artroscópica foram desenvolvidos pelo Professor Kambin (sistema AMD, Smith \& Nephew Dyonics, Inc.,) e evitaram lesões vasculares, pois não permitiram a penetração dos fórceps, lâminas de ressecção ou trefinas no interior do espaço intervertebral acima de 2 centímetros.

\section{TÉCNICA CIRÚRGICA}

$\mathrm{O}$ anestesiologista realizou a sedação com diprivan durante todo o ato cirúrgico. O paciente foi posicionado sobre quatro suportes em decúbito ventral com flexão dos quadris e dos joelhos para retificar a lordose lombar. Em seguida colocou-se o intensificador de imagem no lado sintomático do paciente e posicionou-se um fio de Kirschner na posição antero-posterior paralelo ao espaço discal a ser operado. Foi obtida uma imagem cefálica em $20^{\circ}$ mostrando o espaço discal em toda a sua extensão. Colocou-se o fio metálico na pele e delineou-se com lápis dermográfico referências em 8, 10 e 12 centímetros distante da linha média da coluna vertebral.

$O$ acesso uniportal unilateral foi utilizado e o cirurgião anestesiou a pele, o tecido celular subcutâneo, os músculos quadrado lombar, sacroespinhal, pssoas-ilíaco e a borda externa do anel fibroso, com xylocaína a $2 \%$ associada a vasoconstrictor.

O posicionamento da agulha peridural em relação ao anel fibroso foi de 35 a $45^{\circ}$ em relação ao plano horizontal. Posicionou-se o fio guia no espaço de trabalho triangular que é um espaço extrapedicular permitindo a passagem segura dos instrumentos. Foi limitado anteriormente pelo nervo espinhal, inferiormente pelo bordo do cor-

1) patients who did not fulfill the requisites of the pre-operative questionnaire; 2) cauda equina syndrome; 3) extrusive disc and intracanal migrated herniation (extraligamentous migrated); 4) tumors; 5) psychosocial problems.

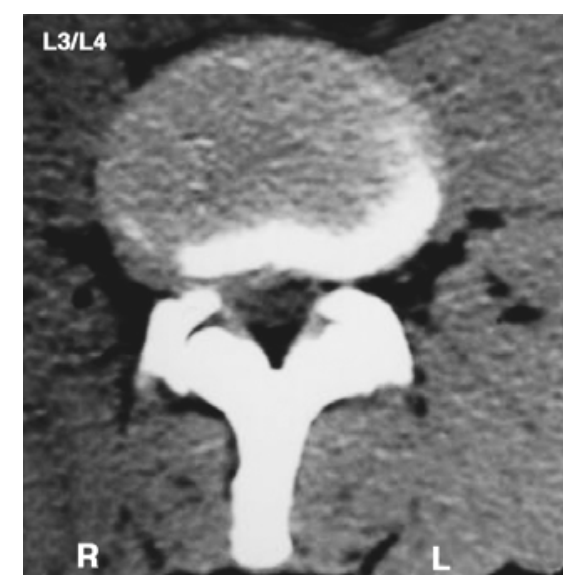

Figura 1- Tomografia axial computadorizada de hérnia discal lombar foraminal à direita.

Figure 1 - Right Foraminal Disc Herniation.

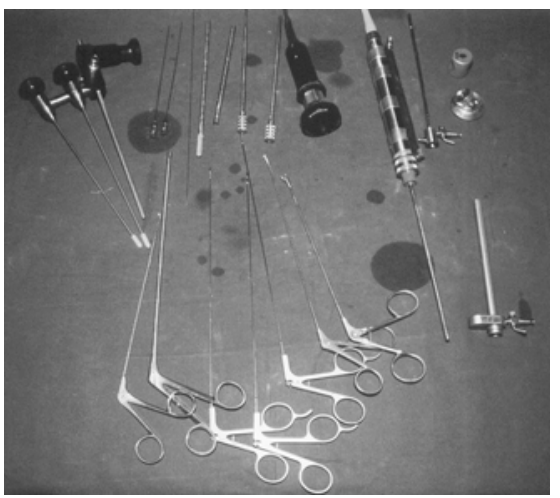

Figura 2 - Instrumentos cirúrgicos. Figure 2 - Surgical Instruments

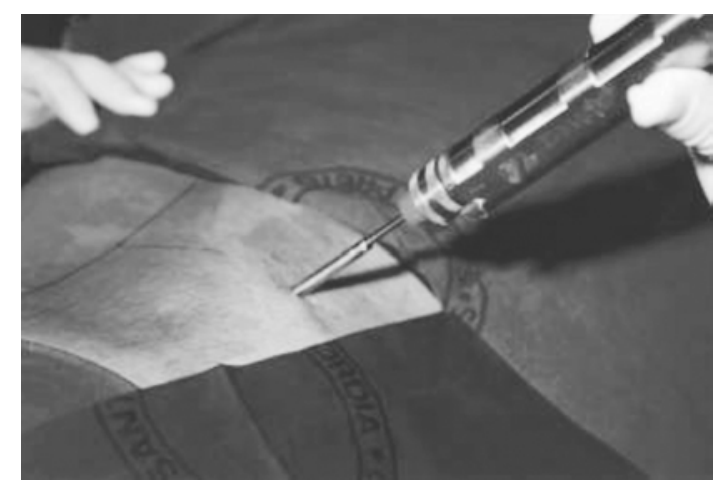

Figura 3 - Nucleótomo automatizado facilita a ressecção discal.

Figure 3 - Automated Nucleotome facilitates expedient disc evacuation.
All the patients completed the "Presurgery Self-assessment Questionnaire", quantifying the intensity of the pain, the frequency of paresis and paresthesia in the affected leg and the degree of capacity for work. During the follow-up in the out-patients clinic the "Post-surgery Self-assessment Questionnaire" was completed in the 3rd and 6th post-operative months. Diagnosis was confirmed by computerized axial tomography and/or nuclear magnetic resonance imaging.

The instruments utilized in the arthroscopic microdiscectomy were developed by Professor Kambin (AMD system, Smith \& Nephew Dyonics Inc.) and avoid vascular lesions as they do not allow greater than 2 centimeters of penetration of the forceps, trimmer blades or trephines inside the intervertebral space.

\section{SURGICAL TECHNIQUE}

Anesthesia was achieved with sedation using diprivan during all the surgery. The positioning of the patient in a recumbent position was on four supports with the hips and knees kept in flexion to correct the lumbar curve. Following this an image amplifier was placed on the affected side of the patient and a Kirschner wire was placed in the anteroposterior position parallel to the disc space to be operated on. A cephalic image of $20^{\circ}$ was obtained of the disc space along all its extension. A metal wire was placed in the skin and the skin was marked using a pencil at 8, 10 and 12 centimeters distance from the midline of the spinal column.

A unilateral uniportal access was utilized. Using 2\% Xylocaine associated with a vasoconstrictor the surgeon anesthetized the skin, subcutaneous cellular tissue, lumbar quadrate muscles, sacrospinal, iliac psoas and the outer border of the fibrous annulus.

The positioning of the peridural needle in respect to the fibrous annulus was at an angle of $35^{\circ}$ to $45^{\circ}$ in relation to the horizontal plane. The guide wire was positioned in the triangular working zone which is an extrapedicular space giving a safe passage for the instruments.

The triangular working zone's anterior boundary is the spinal nerve, lower 
po vertebral lombar inferior e posteriormente pelo processo articular proximal da vertebral inferior. Uma imagem em ântero-posterior foi realizada para demonstrar que a extremidade distal do fio guia estava medialmente ao pedículo, permitindo, no peroperatório, a visualização artroscópica da raiz nervosa e da dura-máter. Para ressecar a hérnia foraminal migrada, o fio manteve-se medial ao pedículo. No perfil, a extremidade do fio guia foi observada posteriormente aos corpos vertebrais. Realizou-se uma incisão de 5 milímetros na pele. A cânula e o sistema obturador foram usados para deslocar a raiz nervosa lateralmente, acessando o local herniado. Nessa fase do procedimento, anestesiaram-se com xylocaína a $2 \%$ e uma solução de $4 \mathrm{ml}$ de soro fisiológico com $1 \mathrm{ml}$ de fentanil os 4 quadrantes do bordo externo do anel fibroso. A inspeção artroscópica da anulotomia foi realizada com artroscópio rígido de $0^{\circ}$ ou $30^{\circ}$, evitandose a lesão neural e sangramento perianular. A fenestração anular foi realizada com 2 trefinas de diâmetros externos de 3 e $5 \mathrm{~mm}$.

A entrada e saída do soro fisiológico foram estabelecidas dentro do artroscópio. Sob visualização e iluminação com instrumentos articulados em $120^{\circ}$ de angulação dorsal, ressecaram-se os fragmentos herniados. O espaço epidural foi inspecionado, assegurando-se da não-existência de fragmentos extraligamentares. Nessa fase, realizou-se a introdução de vários tipos de fórceps especiais e do nucleótomo automatizado para a remoção dos fragmentos nucleares herniados. Em seguida, retirou-se o instrumental e foi dado um ponto com mononylon 5-0 na pele e curativo oclusivo.

\section{RESULTADOS}

Na Tabela 1 são apresentadas as freqüências absolutas, os percentuais e percentuais acumulados das variáveis respostas (dor, paresia, parestesia e capacidade) em cada um dos tempos de observação $\left(t_{1}, t_{2}, t_{3}\right)$, sendo que: $t_{1}$, referiu-se ao pré-operatório, $t_{2}$ a três meses de pós-operatório e $t_{3}$ a seis meses de pós-operatório. Em relação à variável dor, observa-se na Tabela 1 que inicialmente todos os pacientes relataram-na em níveis iguais ou superiores a 8 . Em relação ao tempo 2, 100\% dos pacientes apresentaram níveis de dor menores ou iguais a 3. Relativo ao tempo 3 observa-se que $100 \%$ dos pacientes apresentaram níveis de dor menores ou iguais a 5 , sendo que, $90 \%$ deles estavam abaixo do nível $4,75 \%$ abaixo do nível 3 , $65 \%$ abaixo do nível 2 e $25 \%$ abaixo do nível 1 . De forma geral observa-se melhora dos indivíduos com o passar do tempo, nos quatro quesitos analisados.

Analogamente ao que ocorreu com a variável dor, observou-se também com a paresia e a parestesia. A capacidade de trabalho também melhorou muito em $\mathrm{t}_{3}$ com $100 \%$ apresentando pelo menos $75 \%$ desta e $67 \%$ com capacidade total de trabalhar.

Ao analisar cada paciente, verificou-se que os dados são medidas ao longo do tempo, e então os perfis dos pacientes merecem atenção especial. Para a variável dor a representação gráfica dos perfis (Figura 6). Observaram-se três grupos de pacientes, designados por grupo $A$, aqueles em que se observou melhora em $t_{2}$ e $t_{3}$, representan- is the side of the lower lumbar segment and the posterior boundary is the proximal articular process of the inferior vertebra. An anteroposterior image was made to demonstrate that the distal end of the guide wire was medial to the pedicle, allowing, in the per-operative period, arthroscopic visualization of the nerve root and of the dura mater. To resect the migrated foraminal herniation, the wire was maintained medial to the pedicle or in the lateral extra-foraminal herniation. In the lateral projection, the end of the guide wire was observed posterior to the vertebral bodies. The cannulated obturator was used to laterally displace the nerve root giving access to the herniation. In this phase of the procedure, four quadrants of the outside of the fibrous annulus were anesthetized using 2-\% Xylocaine and a mixture of $4 \mathrm{ml}$ of saline solution with $1 \mathrm{ml}$ of fentanyl. An arthroscopic inspection of the annulotomy was performed with a rigid arthroscope of $0^{\circ}$ or $30^{\circ}$ scope avoiding neural lesion and periannular bleeding. The annular fenestration was achieved with 2 trephines of external diameters of 3 and $5 \mathrm{~mm}$.

The inlet and outlet of the saline soIution irrigation was established inside the arthroscope. Under visualization and illumination with instruments articulating at $120^{\circ}$ dorsal angle, herniated fragments were resected. The epidural space was checked for the existence of extraligamentous fragments. This allowed the insertion of the arthroscope and an uninterrupted visualization of the herniated nuclear material. In this phase, several types of special forceps and automated nucleotome were introduced to remove the herniated nuclear fragments. Following this, the instruments were withdrawn and a single suture was made using 5-0 mononylon and an occlusive dressing was applied.

\section{RESULTS}

In Table 1, the absolute frequencies, percentages and accumulated percentages of the variable responses (pain, weakness, numbness and capacity to work) in each of the time intervals ( $t_{1}$, $t_{2}$ and $t_{3}$ ) are shown. Time interval $t_{1}$ refers to the pre-operative time, $t_{2}$ at three post-operative months and $t_{3}$ at six post-operative months. In relation to the pain, initially $\left(t_{1}\right)$ all the patients reported levels of 8 or greater and at $t_{2}$ all the patients presented with pain levels of less than or equal to 3 . By $t_{3}$ all the patients presented with pain levels less than or equal to 5 , that is $90 \%$ of them were less than 4, 75\% less than 3, 65\% less than 2 and $25 \%$ less than 1. In general an improvement was observed with the passing of time in all four variables.

Analogously what happened with pain, also happened with weakness and paresthesia. The capacity to work also improved very much at $t_{3}$, with all the patients presented with at least $75 \%$ capacity and $67 \%$ with total capacity.

On analyzing each patient, it is possible to see that the measurements are repeated over the time and so the profile of the patients deserves special attention. For pain the graphic repre- 
do $60 \%$ do total, grupo $\mathrm{B}$ aquele em que os pacientes se mantiveram em $t_{3}$ no mesmo nível de $t_{2}$, representando $20 \%$ do total e grupo $\mathrm{C}$, representando os $20 \%$ restantes, o daqueles em que no tempo 3 houve um retrocesso de níveis de dor. sentation of the profiles can be seen in Figure 6. Three groups of patients can be seen denominated as:

Group $A$; those in which an improvement is observed at $t_{2}$ and $t_{3}$, representing $60 \%$ of the patients.

\section{DISCUSSÃO}

A literatura dessa técnica está pouco divulgada nos veículos científicos e, portanto, tivemos dificuldades quanto ao número de trabalhos de pesquisa.

Os maus resultados clínicos com a laminectomia e discectomia aumentaram as pesquisas para técnicas alternativas de descompressão. No padrão ouro de comparação permanecem a laminectomia (ou laminotomia) e discectomia.. As heniações lombares foraminais são particularmente bem removidas pela técnica de microdiscectomia artroscópica póstero-lateral. A hérnia foraminal é o tipo ideal para esse procedimento por estar localizada diretamente no final da cânula de acesso, sendo visualizada pelo endoscópio e removida com fórceps. O endoscópio tipo canal do trabalho permite a visualização da herniação sem a necessidade da ressecção facetária que pode levar à instabilidade segmentar. Nos pacientes idosos, o núcleo discal está geralmente desidratado, e a compressão mecânica da raiz nervosa é causada pela protrusão das fibras do anel fibroso associadas com estenose do recesso lateral ou central. Quando esses discos são abordados póstero-lateralmente encontramos uma cavidade e, em muitos casos, pou-

\begin{tabular}{|c|c|c|c|c|c|c|c|c|c|c|}
\hline \multirow{2}{*}{\begin{tabular}{|l} 
Variável \\
Dor \\
\end{tabular}} & \multirow[b]{2}{*}{ Níveis } & \multicolumn{3}{|c|}{ Tempo1 } & \multicolumn{3}{|c|}{ Tempo2 } & \multicolumn{3}{|c|}{ Tempo3 } \\
\hline & & $\mathbf{n}_{1}$ & $\%$ & \%acum & $\mathbf{n}_{1}$ & $\%$ & \%acum & $n_{1}$ & $\%$ & \%acum \\
\hline & 0 & & & & & & & 1 & 5 & 5 \\
\hline & 1 & & & & & & & 4 & 20 & 25 \\
\hline & 2 & & & & 8 & \begin{tabular}{|l|}
40 \\
\end{tabular} & 40 & 8 & \begin{tabular}{|l|}
40 \\
\end{tabular} & 65 \\
\hline & 3 & & & & 8 & \begin{tabular}{|l|}
40 \\
\end{tabular} & 80 & 2 & \begin{tabular}{|l|}
10 \\
\end{tabular} & 75 \\
\hline & 4 & & & & & & & 3 & 15 & 90 \\
\hline & 5 & & & & 3 & 15 & 95 & 2 & \begin{tabular}{|l|}
10 \\
\end{tabular} & 100 \\
\hline & 6 & & & & 1 & 5 & 100 & & & \\
\hline & 7 & & & & & & & & & \\
\hline & 8 & 5 & 25 & 25 & & & & & & \\
\hline & 9 & 8 & 40 & 65 & & & & & & \\
\hline & 10 & 7 & \begin{tabular}{|l|}
35 \\
\end{tabular} & 100 & & & & & & \\
\hline & Total & 20 & 100 & 100 & 20 & 100 & 100 & 20 & 100 & 100 \\
\hline \multicolumn{11}{|l|}{ Fraqueza } \\
\hline & 1 & & & & & & & 4 & 20 & 20 \\
\hline & 2 & 1 & 5 & 5 & 17 & 85 & 85 & 15 & \begin{tabular}{|l|}
75 \\
\end{tabular} & 95 \\
\hline & 3 & 14 & 70 & 75 & 3 & 15 & 100 & 1 & 5 & 100 \\
\hline & 4 & 5 & 25 & 100 & & & & & & \\
\hline & 5 & & & & & & & & & \\
\hline & \begin{tabular}{|l|} 
Total \\
\end{tabular} & 20 & 100 & 100 & 20 & 100 & 100 & 20 & 100 & 100 \\
\hline \multicolumn{11}{|l|}{ Dormência } \\
\hline & 1 & & & & & & & 1 & 5 & 5 \\
\hline & 2 & & & & 11 & 55 & 55 & 15 & \begin{tabular}{|l|}
75 \\
\end{tabular} & 80 \\
\hline & 3 & 2 & 10 & 10 & 8 & 40 & 95 & 4 & 20 & 100 \\
\hline & 4 & 15 & \begin{tabular}{|l|}
75 \\
\end{tabular} & 85 & 1 & 5 & 100 & & & \\
\hline & 5 & 3 & \begin{tabular}{|l|}
15 \\
\end{tabular} & 100 & & & & & & \\
\hline & \begin{tabular}{|l|} 
Total \\
\end{tabular} & 20 & 100 & 100 & 20 & 100 & 100 & 20 & 100 & 100 \\
\hline \multicolumn{11}{|l|}{ Capacidade } \\
\hline & 1 & & & & & & & 10 & 50 & 50 \\
\hline & 2 & 2 & 10 & 10 & 15 & 75 & 75 & 7 & \begin{tabular}{|l|}
35 \\
\end{tabular} & 85 \\
\hline & 3 & 15 & 75 & 85 & 5 & \begin{tabular}{|l|}
25 \\
\end{tabular} & 100 & 3 & 15 & 100 \\
\hline & 4 & 3 & \begin{tabular}{|l|}
15 \\
\end{tabular} & 100 & & & & & & \\
\hline & & & & & & & & & & \\
\hline & Total & 20 & 100 & 100 & 20 & 100 & 100 & 20 & 100 & 100 \\
\hline
\end{tabular}

Tabela 1 - Distribuição de respostas por variável, apresentando para cada tempo $t_{1}$ (pré-operatório), $t_{2}\left(3\right.$ meses de pós-operatório) e $t_{3}(6$ meses de pós-operatório), a freqüência absoluta $(n)$, porcentagem (\%), porcentagem acumulada (\%acum.).

Table 1: Distribution of the responses by variable, presenting for each time $\left(t_{1}, t_{2}\right.$ and $\left.t_{3}\right)$ the absolute frequency $(n)$, percentage (\%), and accumulated percentage (\% accum.)
Group B; those who maintained the same level at $t_{3}$ as at $t_{2}$ representing $20 \%$ of the patients.

Group C; representing the final $20 \%$ in whom there was deterioration in the pain levels at $t_{3}$.

\section{DISCUSSION}

We had dificulties to get research papers about arthroscopic microdiscectomy because the literature about this technique is a little spread by scientific vehicles.

The bad clinical results of laminectomy and discectomy encouraged more research for alternative methods of decompression. The gold standard for comparison continues to be laminectomy (or laminotomy) and discectomy. Foraminal or extraforaminal herniations are removed particularly well by arthroscopic posterolateral microdiscectomy. The foraminal herniation is the ideal type for this procedure as it is located right at the end of the cannula. Visualization and removal of the herniation using simple pituitary ronguers is very easy. The working channel scope allows visualization of the herniation during its resection without the necessity of facetary resection which can lead to seg-
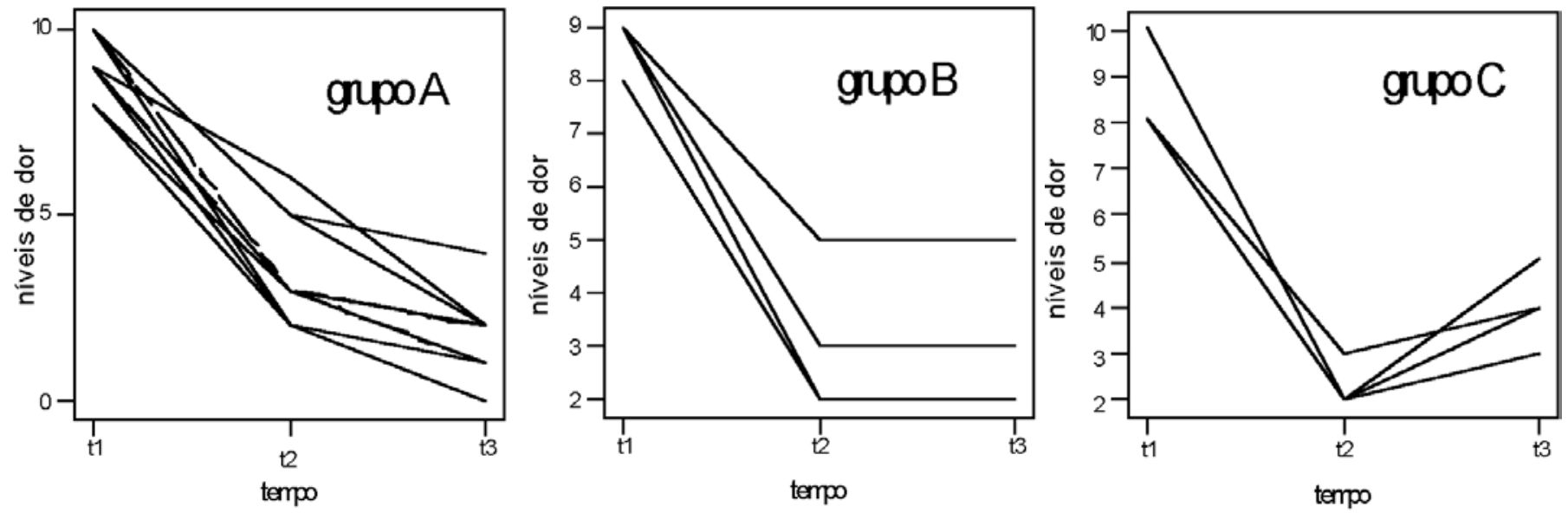

Figura 6 - Perfís individuais dos níveis de dor Fig.6- Graphic representation of pain profiles. 
co ou nenhum material nuclear ${ }^{(9)}$. Deve ser ressaltado que a estenose do recesso lateral é geralmente associada ao insucesso da microdiscectomia artroscópica.

Por outro lado, os discos seqüestrados não são passíveis de serem ressecados pela técnica descrita. Se não for possível diferenciar entre um fragmento seqüestrado não deslocado ou extrusão parcial e uma hérnia contida nas imagens de rotina da tomografia axial computadorizada e/ou ressonância magnética, deve ser realizada uma tomografia associada à discografia, que demonstrará um extravasamento do material radiopaco no local da herniação e poderá delinear claramente o fragmento seqüestrado.

Peterson $^{(14)}$, operou hérnias foraminais e extraforaminais pela descompressão póstero-lateral artroscópica. Nos 41 pacientes com seguimento de 1 ano, obteve $88 \%$ de sucesso e na sua casuística mostrou 5 maus resultados, com 3 deles sendo reoperados e 2 que não referiram melhora.

Reynolds et al ${ }^{(15)}$ conseguiram $80 \%$ de bons resultados usando os critérios de inclusão do Professor Kambin. Os dois diferentes estudos prospectivos de Kambin ${ }^{(7,10)}$ mostraram $88,1 \%$ de bons resultados em 275 pacientes avaliados. Yeung ${ }^{(16)}$ operou 185 pacientes pela mesma técnica e obteve $85 \%$ de bons resultados. Mayer e Brock ${ }^{(12)}$ apresentaram resultados de estudos prospectivos randomizados de 40 pacientes que foram operados pela microdiscectomia via posterior ou pela microdiscectomia artroscópica póstero-lateral. Dois anos após constataram o desaparecimento da ciática em $80 \%$ nos pacientes que fizeram o procedimento endoscópico, enquanto no acesso aberto houve melhora de $65 \%$. Em relação ao déficit sensitivo, o grupo da microdiscectomia artroscópica teve $92,3 \%$ e com a microdiscectomia aberta ocorreu em $68,8 \%$. Quanto ao retorno ao trabalho original, 95\% do grupo artroscópico e o da cirurgia aberta, apenas $72,2 \%$. Nossos resultados comparativos com os de Mayer e Bro$\mathrm{ck}^{(12)}$, no $6^{\circ}$ mês de pós-operatório, evidenciaram que $75 \%$ dos pacientes tinham dor ocasional e $65 \%$ possuíam raros episódios. Além disso, 95\% com episódios raros de paresia e $80 \%$ dos indivíduos relataram parestesia. Do total de pacientes, $85 \%$ tiveram sua capacidade de trabalho restabelecida. Nesse grupo de vinte pacientes, três foram reoperados por quadro de dor rebelde após o quarto mês pela microdiscectomia convencional, obtendo alívio da dor. As complicações relacionadas com o posicionamente da agulha e do instrumental ocorreram em 5 pacientes como hipersensibilidade da pele na região lombar e na face lateral da perna sendo tratadas conservadoramente com analgésicos não opiáceos, antidepressivo e fisioterapia contínua, havendo remissão total do quadro. Uma paciente apresentou quadro de dor intensa na coxa e perna direita. A etiologia desse quadro foi a movimentação excessiva no peroperatório por globo vesical distendido e o deslocamento contínuo da cânula de acesso migrando pelo espaço perianular e traumatizando a raiz emergente. Após o cateterismo vesical houve o conseqüente alívio. A hiperestesia persistiu por 2 meses e desapareceu totalmente após esse período. Não houve lesão nervosa motora, vascular ou discite bacteriana em nenhum dos pacientes operados.

Kambin e Zhou ${ }^{(10)}$ relataram que a eficácia a longo prazo e a baixa incidência de reherniação após cirurgia discal artroscópica foram atribuídas a vários fatores. Estes incluem a proteção das estruturas de suporte e mioligamentares pela canulização, evitando a ruptura das mesmas; prevenção da formação da escara epidural e perineural ao não penetrar no canal lombar; não lesa o sistema venoso epidural, que pode levar a edema e fibrose crônica do nervo e preservação das fibras do anel fibroso póstero-lateral e posterior durante a cirurgia

Kambin et al ${ }^{(9)}$ ressaltaram que as limitações do acesso pósterolateral incluem dificuldades associadas com a remoção dos fragmentos discais seqüestrados e o acesso ao nível L5-S1 na presença de crista ilíaca elevada que é prevalente no sexo masculino. $\mathrm{O}$ avanço das pesquisas no campo da cirurgia minimamente invasiva facilitará mental instability. In aged patients, the disc nuclear mass is generally dehydrated, and the mechanical compression of the nerve root is caused by protrusion of the fibers of the fibrous annulus associated with stenosis of the lateral or central recess. When these discs are dorsal-laterally approached a cavity, and in many cases little or no nuclear mass, is discovered ${ }^{(9)}$. It must be emphasized that stenosis of the lateral recess is generally associated with unsuccessful arthroscopic microdiscectomy.

On the other hand, it is not possible to resect sequestered discs by the above technique. If it is not possible to differentiate between a non-dislocated sequestered fragment or partial extrusion and of the herniation from the routine computerized axial tomography images and/or magnetic resonance, then a tomography associated with discography should be performed to demonstrate the surplus radiopaque material at the site of the herniation and to clearly delimit the sequestered fragment.

Peterson ${ }^{(14)}$ operated foraminal and extraforaminal hernias by arthroscopic posterolateral decompression. Of 41 patients accompanied over one year, he obtained an $88 \%$ success rate and in his casuistic there were 5 bad results, three who underwent reoperations and two who did not report any improvement.

Reynolds et a/(15) achieved an $80 \%$ rate of good results using the inclusion criteria of Professor Kambin. The two different prospective studies of Kambin ${ }^{(7,10)}$ demonstrated an $88.1 \%$ success rate in 275 assessed patients. Yeung ${ }^{(16)}$ operated on 185 patients by the same technique and achieved a success rate of $85 \%$. Mayer \& Brock ${ }^{(12)}$ presented results from prospective randomized studies of 40 patients who underwent posterior microdiscectomy or posterolateral arthroscopic microdiscectomy. Two years after the surgery, the disappearance of the sciatic pain was evidenced in $80 \%$ of the patients who made the endoscopic procedure whilst in the open access patients there was an improvement of $65 \%$. In relation to sensitivity deficit, the arthroscopic microdiscectomy group had $92.3 \%$ and with the open microdiscectomy group there was $68.8 \%$. A total of $95 \%$ of the arthroscopic group and $72.2 \%$ of the open surgery group were able to return to their original occupation. Our results compared with Mayer \& Brock in the sixth post-operative month we evidenced that $75 \%$ of the patients had occasional pain and $65 \%$ had rare episodes. Apart from this, 95\% had rare episodes of paresis and $80 \%$ of the individuals reported paresthesia disappeared completely. A total of $85 \%$ had their capacity to work reestablished. In this group of twenty patients, 3 were reoperataded due severe leg pain by open microdiscectomy after four months and recovered well.

Complications relating to the placing of the needle and the instruments occurred in five patients who had hypersensitivity of the skin in the lumbar region and the lateral face of the leg and who were conservatively treated using non-opiate analgesics, antidepressive agents and continuous physiotherapy. After this treatment there were remission of the clinical findings. One patient presented with very intense pain in the right leg and thigh. The etiology of this pain was excessive movement in the per-operative period distended vesical globe and the continuous movement of the access cannula migrating to the periannular space thus injuring the emerging root. After vesical catheterism there was consequent relief. Hyperstesia persisted for 2 months. There was no motor nerve or vascular lesions or bacterial discitis.

Kambin and Zhou ${ }^{(10)}$ related the efficacy over the long term and low incidence of re-herniation after the arthroscopic disc surgery was attributed to several factors. These include the protection of the support and fine dural and neural ligamentous structures by the cannula, avoiding rupture; prevention of the formation of epidural and perineural scaring by not penetrating the 
o acesso artroscópico e descompressão das raízes nervosas nesse grupo de pacientes.

\section{CONCLUSÕES}

A microdiscectomia artroscópica foi eficaz no tratamento das hérnias discais lombares foraminais (interespaço das $4^{a}-5^{a}$ vértebras), constituindo uma alternativa prévia ao tratamento aberto.

Os benefícios clínicos observados nesta técnica, foram: redução da dor incisional, menor tempo de internação, melhores resultados cosméticos, rápida recuperação e retorno precoce às atividades normais. lumbar canal, not injuring the epidural venous system which can lead to edema and chronic fibrosis of the nerve and preservation of the fibers of the posterolateral and posterior fibrous annulus during the surgery.

Kambin, et $\mathrm{a}^{\left({ }^{(9)}\right)}$ refered the limitations of the posterolateral approach include difficulties associated with the removal of sequestered disc fragments and access to the L5-S1 intervertebral discat the presence of elevated iliac crest that is prevalent in men. The ongoing development of research in the field of minimally invasive surgery facilitates arthroscopic access and decompression of the nerve roots in this group of patients.

\section{CONCLUSIONS}

Arthroscopic microdiscectomy was efficient in the treatment of protrusive foraminal lumbar disc herniations (between the 4th and 5th vertebrae), constituting an alternative to open surgery.

The clinical advantages observed in this technique were: reduction of pain in the local of incision, better cosmetic results and fast recovery to daily life activities.

\section{REFERÊNCIAS BIBLIOGRÁFICAS}

1. Abdullah AF, Ditto E, Byrd E, Williams R. Extreme lateral lumbar disc herniation. J Neurosurg 4l:229-234, 1974

2. Dandy WE. Concealed ruptured intervertebral discs. JAMA 117:821-823, 1941

3. Grenier N, Greselle J, Douws C, et al. MR Imaging of foraminal and extraforaminal lumbar disc herniations. J Comput Assist Tomogr 14:243-249, 1990.

4. Harris RI, MacNab I. Structural changes in the lumbar intervertebral discs. Their relantionship to low back pain and sciática. J Bone Joint Surg Br 38:304-322, 1954.

5. Hijikata S. Percutaneous nucleotomy: a new concept. Technique and 12 years experience. Clin Orthop 238:9-23. 1989

6. Kambin P, Brager M. Percutaneous posterolateral discectomy. Anatomy an mechanism. Clin Orthop 223:145-154, 1987

7. Kambin P, Casey K, O'Brien E, Zhou L. Transforaminal arthroscopic descompression of lateral recess stenosis. J Neurosurg, 84:462-467, 1996.

8. Kambin P, O'Brien E, Zhou L. Arthroscopic microdiscectomy and fragmentectomy. Clin Orthop 347:150-167, 1998

9. Kambin P, Schaffer JL, Zhou L. Incidence of complications following percutaneous posterolateral arthroscopic disc surgery. Orthop Trans 19:404-405, 1995.
10. Kambin P, Zhou L. Arthroscopic discectomy of the lumbar spine. Clin Orthop 337:49-57, 1997

11. Lindblom K. Protrusions of discs and nerve compression in the lumbar region. Acta Radiol 25:195-212, 1944

12. Mayer HM, Brock M. Percutaneous endoscopic discectomy: surgical technique and preliminary results compared to microsurgical discectomy. J Neurosurg 78:216-225, 1993.

13. McCulloch JA, Young PH. Foraminal and extraforaminal lumbar disc herniation. In: Essentials of spinal microsurgery. Philadelphia: Lippincott-Raven 21:383 427, 1988.

14. Peterson R. Effectiveness of arthroscopic microdiscectomy in the treatment of foraminal and extraforaminal disc herniation, new horizons in spinal surgery, (notes) Allegheny University Hospitals, Philadelphia, PA, Nov. 1-2, 1996

15. Reynolds J, Goldthwaite N, White A et al. Arthroscopic microdiscectomy (AMD) for lumbar disc protrusion, San Francisco Spine Institute, Daly City, California Personal Communication.

16. Yeung A, A.M.D. The evolution from central nucleotomy to posterior and lateral fragmentectomy arthroscopic microdiscectomy of the lumbar spine (notes), international symposium abbott norhwestern hospital university of Minnesota, Minneapolis, Minnesota, October 6-7, 1995 